\title{
NEW CRITERIA OF ENVIRONMENTAL CONTROL FOR ACTIVITIES IMPLEMENTATION IN VALENCIAN URBAN MANAGEMENT
}

\author{
MARIA TERESA BROSETA PALANCA \\ Departamento de Urbanismo, Universidad Politécnica de Valencia, España.
}

\begin{abstract}
All instruments for environmental administrative supervision are aimed to control those facilities and activities likely to cause discomfort, alter environmental health conditions, or cause risk or harm to individuals or the environment.

The rules adopted for this purpose determine the start-up and performance of certain facilities to secure an authorisation of an environmental nature, which will be processed in a coordinated manner when the procedure involves more than one administrative authority with competence in such matters. Also, the integration of the processes of the two main systems of administrative intervention to prevent and reduce pollution at sources should be coordinated; such systems are the Integrated Environmental Authorisation and Environmental Impact Assessment.

Depending on the higher or lower capacity of the contaminant level to be managed, the control of the installation is adjusted in a way that the facilities, which host potentially harmful concentrations, have a more complex procedure of control under the oversight of regional administration; meanwhile, those of lower degree of potential impact on the environment are controlled by local councils, regardless of their resources.

New measures to reduce the terms and costs in activities implementation are included in recent regulation to launch productive activities and job creation, with new legal requirements including the Environmental Liability Statements and Environmental Communication. These tools have been created to reduce bureaucracy, and have caused local councils to change their ordinances to face this new challenge, although useful results have not yet been demonstrated.

Keywords: environmental impact assessment, environmental permits, industrial emissions, integrated environmental authorisation.
\end{abstract}

\section{INTRODUCTION}

The environmental protection system for non-residential activities has become a complex procedure in which different stages of protection must be overcome.

The implementation control by urban planning requires the territorial environmental assessment of structural character, delimiting those zones where the activities of highest impact can be placed.

Secondly, by means of detailed planning in new developable sectors, the main uses are defined, as well as the compatible and incompatible ones in each zoning district, following the strategic environmental assessment of the plan.

On a small scale, in isolated plots, the activity is subject to the examination of the Environmental Authorisation process that may be strengthened with the addition of the environmental impact assessment for several activities submitted to the double system of protection [1]. 
The implementation of successive levels of control turns the Spanish system into one with a high guarantee despite the loss of agility that is detrimental to private investment in productive activities.

Regarding this administrative structure, it would be necessary to research on the objectives of each control phase to clarify those competences that could be joined to achieve a swift process.

\section{THE FIRST STEP: ENVIRONMENTAL CONTROL BY DETAILED PLANNING}

\subsection{Control of activities in urban and developable land}

Apart from the first step of environmental assessment of regional character, the control of new activities in urban land, developable or consolidated, in the scope of one township, can be established according to environmental needs by a detailed plan. Through the index cards of the planning documents linked to arrangement plans, a list of activities can be permitted or rejected depending on the damaging level of the exploitation.

In fact, the assessment for this plan, according to law, follows a simplified procedure that is not an evaluation itself; rather, the actions are intended to determine whether the plan must pass a complete assessment or not, due to its possible adverse or significant impact on the environment, the conclusions of which will be gathered in a report [2].

The new criterion of assessment according to the Valencian Urban Law modification made by Law 10/2015, of December 29th, about Tax Measures, Administrative and Finance Management and Government Organization, consists in the changing of assessment competence, in such way that it is transferred from the regional body to town halls. From this moment, local administration must be able to manage the files of environmental assessment for the detailed planning of urban areas and developable land. In accordance with the same law, in cases of small townships with limited resources, local administrations can count on the help of provincial government. By this measure, the objective is, among others, reducing the terms of the assessment process by lightening the competences gathered in just one body of the administration [3].

\subsection{Control of activities in rural land}

In general terms, the non-developable land cannot be used for other purposes than agricultural, forestry, livestock, or hunting activities, or those related to the rational use of natural resources. Exceptionally, other uses and urban exploitation may be conferred, but only when strictly necessary and whenever this is essential because of the location of this sort of land.

Zoning in non-developable lands may foresee, according to their characteristics and with exceptional nature, the following uses and exploitations (Article 197, Valencian Urban Law):

a. Buildings and livestock installations, farming, hunting activities, and forestry facilities as well as those for fish farms inland, agricultural products stores, ornamental plants or fruit trees, that are produced in the farm that is linked to.

b. Isolated family housing.

c. Quarries exploitation; extraction of aggregates (crushed stone), sand, and gravel; and geological or hydrological resources.

d. Renewable energy generation in accordance with the sectorial legislation and planning.

e. Industrial and productive activities with a required location in rural and isolated positions.

f. Tertiary sector (or service sector) activities. 
40 Environmental and Economic Impact on Sustainable Development

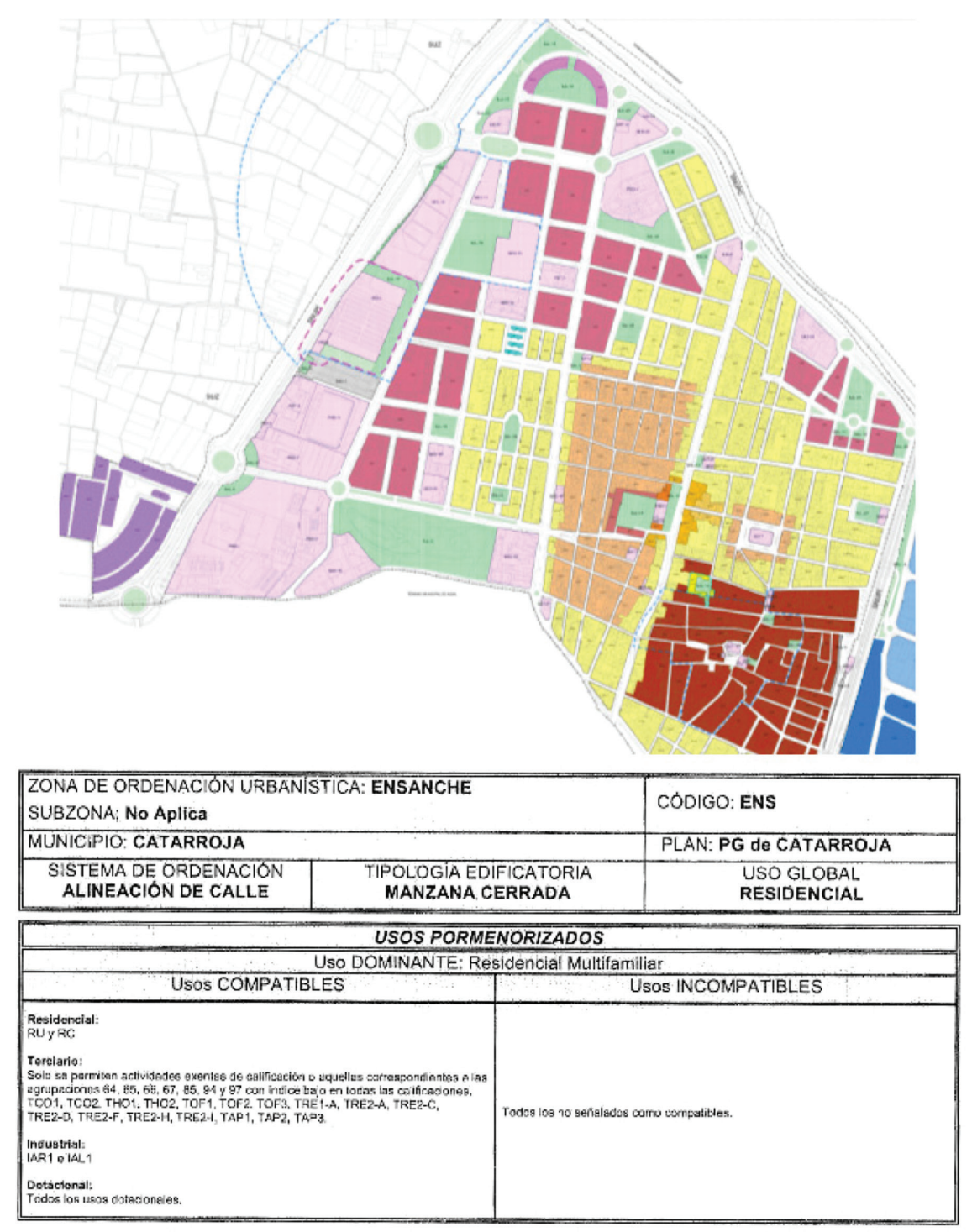

Figure 1: Index card of detailed planning in the zoning district of Expansion in the township of Catarroja (Valencia). The table describes the detailed compatible and incompatible activities in the zones of Expansion, zones that look in intense pink colour in the plan.

By means of the Statement of Community Interest (SCI) issued by the regional administration, prior to the municipal license, a final set of three activities may be permitted that include renewable energy generation, industrial and productive activities, and tertiary sector (or service sector) activities.

Moreover, the authorisation of use and exploitation by the SCI requires a study of landscaping integration, and, where appropriate, the statement of environmental impact assessment will be issued in advance of the Integrated Environmental Authorisation or environmental permit of activity [4] From the research by Espinosa Baviera in 2015 [5], the average term of 


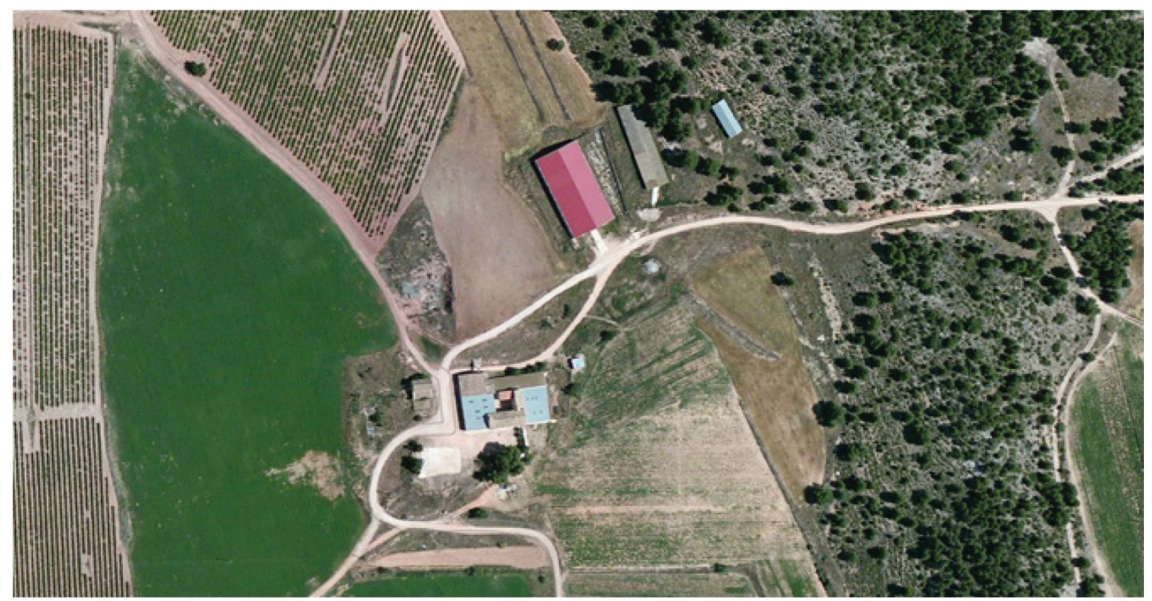

Figure 2: Industrial unit installation for a wine cellar, through a statement of community Interest in rural land, township of Ayora (Valencia).

an SCI proceeding is 1 year, but can be extended to 2 years, without considering other possible proceedings being included, as explained above.

Especially in the case of industrial, productive, and tertiary or service activities, given their ability to create jobs, the competent Consellería in urban planning may accept by proposal from local government the urgent processing of the request. In this case, the periods are reduced by half.

A recent rule in Valencian Urban Law (2014) excludes from the SCI rural lodging, wine cellars, and restaurants implemented in the vernacular architecture of residential, rural, or industrial use.

\section{REGIONAL CONTROL: ENVIRONMENTAL IMPACT ASSESSMENT VERSUS INTEGRATED ENVIRONMENTAL AUTHORISATION}

As mentioned previously, once the plan has been assessed by authorities and before any installation is built on the sector, the project of the installation will be controlled by administration to pass Environmental Impact Assessment and Integrated Environmental Authorisation, according to national legislation based on previous European Directives.

The EIA European Directive (85/337/EEC) is in force since 1985 and has been amended three times by D97/11/EC, D2003/35/EC and D2009/31/EC. The initial Directive of 1985 and its three amendments have been codified by Directive 2011/92/EU of 13 December 2011, recently amended by Directive 2014/52/EU. The Directive 2010/75/EU on industrial emissions (IED) sets out the main principles for the permitting and control of installations based on an integrated approach and the application of best available techniques to achieve a high level of environmental protection, taking into account the costs and benefits. On 7 January 2014, the IED repealed and replaced Directive 2008/1/EC on integrated pollution prevention and control, Directive 2000/76/EC on waste incineration, Directive 1999/13/EC on activities using organic solvents and Directives 78/176/EEC, 82/883/EEC and 92/112/EEC, concerning titanium dioxide production [6]. 
42 Environmental and Economic Impact on Sustainable Development

\subsection{Environmental impact assessment}

In the Valencian Community, for the first time, environmental assessment is regulated by Law 2/1989, of March 3rd, of the Generalitat Valenciana, regarding Environmental Impact, and developed by Decree 162/1990 of October 15th (amended by Decree 32/2006, March 10th). The competent administration to deliver the Impact Assessment Statement is the Conselleria of Housing, Public Works and Territory Support.

The list of projects under the Environmental Impact Assessment appears in the Annex of the Law 2/1989, March 3, and includes, in addition to those indicated in Table 1, the projects for aqueducts, oil and gas pipelines, and other infrastructures including motorways, rapid routes, and railways; airports and heliports not of general interest, and private airports; refuge harbours, marinas, and fishing ports as well as any work in harbour to increase inland space, dams, and river channels. Regarding planning instruments, the EIA is mandatory for master plans and development plans, in addition to their amendments in non-developable land and in developable land of industrial use.

We are facing an instrument of preventive nature and management function consisting of a legal-administrative procedure aimed at the identification, prediction and interpretation, and reporting of the environmental impacts that a specific project or activity may cause if it is implemented, as well as the prevention, correction, and assessment of them, all with the purpose of having the construction accepted, modified, or rejected [7].

\subsection{Integrated environmental authorisations}

Activities shall be subject to the regulation of Integrated Environmental Authorisation in terms where they may cause significant impacts on the environment in which they are developed; this may also involve the exploitation of the facilities, whether public or private ownership, in which are developed any of the activities included in Annex I in law 6/2014, of 25 July (Table 1).

Permission will precede the construction, installation, or relocation of facilities, and it will be adapted to the amendments that may occur in them.

The permit is intended to reduce source emissions into air, water, and soil and to reduce waste generation, with the implementation of technical improvements that have been validated by the European Union and to integrate in a single act of administrative intervention all environmental permits and environmental impact assessments from the regional authority.

The competent body for processing and resolving the procedure is the Conselleria of agriculture, environment, climate change and rural development. Once the authorisation is granted, it will be in force for a maximum period of 8 years; the submission of the application to the competent body must be attached with the following documentation:

a. The basic project of activity drafted and signed by a competent technician.

b. Environmental impact assessment.

c. Municipal urban report about land classification and use compatibility.

d. Statement of community interest when the project is to be located on non-developable land.

Once it is proven that the documentation has been completed, the competent body shall publish in the Official Journal of Valencian Community the public exhibition of the file for 30 days and shall notify the same term of 30 days for bringing audience to the owners of the 


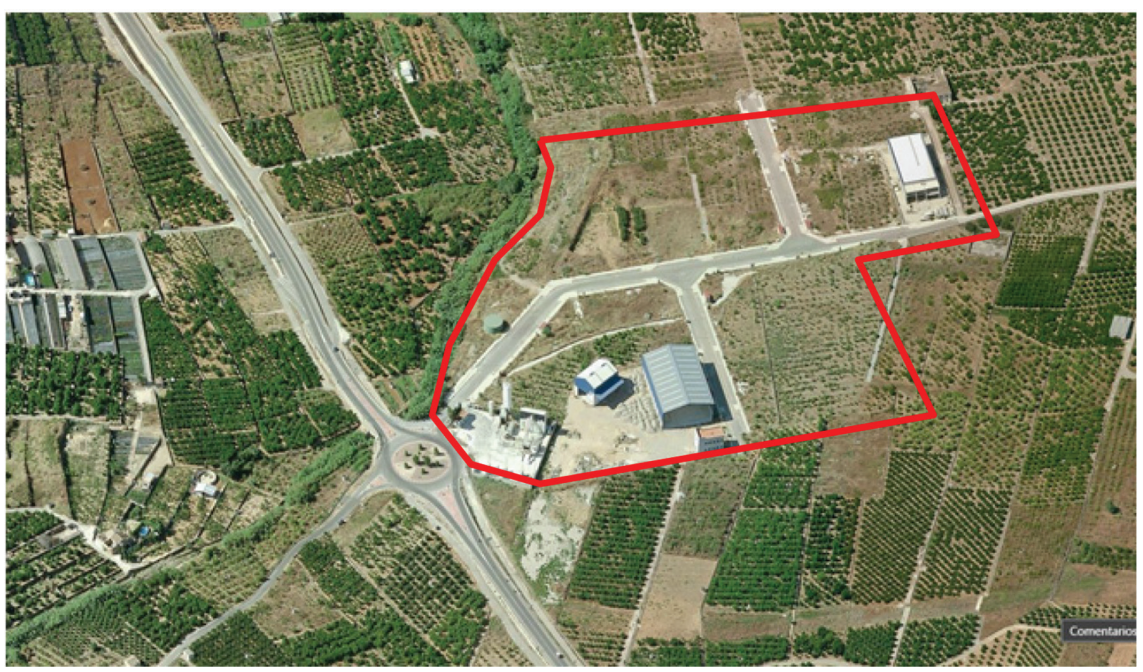

Figure 3: Industrial units in a new industrial park in developable land in the township of Ador (Valencia) with different environmental control processes based on the activity level of impact.

Table 1: Coinciding fields of assessment by environmental impact and environmental authorisation.

\begin{tabular}{|c|c|}
\hline $\begin{array}{l}\text { Activities included in Annexes of Law, subject to } \\
\text { environmental control of activities (Law 6/2014) }\end{array}$ & $\begin{array}{c}\text { Activities Subject to Environmental Impact } \\
\text { Assessment or to previous report to estimate } \\
\text { the assessment (Law 2/1989 and Decree } \\
162 / 1990)\end{array}$ \\
\hline 1. Combustion Plants & YES \\
\hline 2. Production and Processing of Metals & YES \\
\hline 3. Mineral Industries & YES \\
\hline 4. Chemical Industry & YES \\
\hline 5. Waste Management & YES \\
\hline 6. Wood Products Industry & YES \\
\hline 7. Textile Industry & NO \\
\hline 8. Leather Industry & NO \\
\hline 9. Agri-food Industries and Livestock Holdings & YES \\
\hline 10. Consumption of Organic Solvents & NO \\
\hline 11. Carbon Industry & NO \\
\hline 12. Wood Preservation Industry & NO \\
\hline 13. Water Treatment & YES \\
\hline 14. $\mathrm{CO}_{2}$ Capture & NO \\
\hline
\end{tabular}


44 Environmental and Economic Impact on Sustainable Development

adjoining plots. At the same time, a section of public participation related to the project is placed on the website of the Environment Conselleria.

The issue of sectorial reports is mandatory and binding consideration in case of being unfavourable or for applying corrective measures.

When the project is subject to Environmental Impact Assessment, after finishing the public information procedure, a copy of the dossier will be forwarded to the Environmental Agency, with all allegations received, and attached, where appropriate, with the comments as deemed necessary to enable an Environmental Impact Statement within a maximum period of 2 months from receipt of the dossier.

Where appropriate and once the construction of facilities has been completed but before the start of the activity, the holder of the activity shall make a Liability Statement for the start of the activity to the competent administration, accompanied by the regulatory documentation.

During the following month after the submission of the Liability Statement, the administration can conduct a verification visit. After a month without opposition or objections or without this visit having been made, the performance of the activity may be started.

The average term of proceeding in the 635 authorisations given in the Valencian Community is from 1.5 to 2 years, but it can be extended until 4 years [8].

\subsection{Convergence of environmental impact assessment and integrated environmental authorisation}

The research on the fields of assessment through knowledge about the minimum contents of the documents required by each process, allows identification of the overlaps between both systems.

According to the Order by the Conselleria of Housing and Territory (2005, January 3), the minimum content of the Environmental Impact Study to be examined must describe the following:

a. General features of the project and the foreseen requirements related to the use of land and other natural resources during the term of construction and function.

b. Industrial process or the exploitation or function process, with the estimation of kind and quantity of residues and foreseen emissions such as water, air, and soil pollution; noise and vibration; light; heat; and radiation.

c. Alternative solutions studied by technicians, indicating the main reasons to select one of them.

d. Environmental elements liable to be impacted by the proposed project, especially population, fauna, flora, land, air, climate factors, goods, heritage architecture, archaeological resources, and landscape, and interactions among them.

e. Foreseen effects over the described environmental elements and method of valuating them.

f. Corrective measures adopted to reduce, remove, or compensate the negative effects on the environment.

g. Final conclusions and report, if necessary, about the difficulties of technical character found during the study development.

h. Environmental vigilance programme.

In comparison with the minimum contents of the Basic Project of Activity to pass the Integrated Environmental Authorisation, established by Law 6/2014 of July 25, the specifications 
in points (a), (b), (c), and (f) coincide; meanwhile, the points (e), (g), and (h) are exclusive of the Environmental Impact Studies, and the point d) is already controlled by planning assessment.

Therefore, the field of assessment in both proceedings is the same in fifty per cent of the contents, and more than the ten per cent of the contents have been evaluated in previous proceedings.

Concerning evaluated activities, the scopes are coincident, as well, as demonstrated in Table 1, where eight of the fourteen fields of evaluation are considered by both norms. However, the levels of parameters to establish the need of assessment are not similar in both norms, and sometimes the report by an expert is necessary to interpret them.

\section{LOCAL ENVIRONMENTAL CONTROL}

\subsection{Environmental permits}

The aim of the environmental permit consists of evaluating the conditions of the activity for the environment in order to monitor air emissions, water and soil, and to ensure proper waste management, so that the municipal authority, charged with granting the permit, remains tied to the resolution of the Territorial Commission for the Integrated Environmental Analysis.

Following the criterion of less impact level, the group of activities subjected to the process is included in Annex II of Law 6/2014.

In this case, the competent body for processing and granting the permit is the city council of the town, where the activity will ultimately be developed. Nevertheless, the binding environmental opinion about the granting of the environmental permit shall be the Territorial Commission for the Integrated Environmental Analysis, for those municipalities with a population of fewer than 10,000 inhabitants (or exceptionally with a lack of personal and technical means and with populations up to 50,000 inhabitants), and the City Council itself when its population is equal to or higher than this threshold.

The term of an environmental permit, once granted, is unlimited, without prejudice to the renewal of the license, to substantial facility modifications, or to changes of the type of activity.

Before the application for an environmental permit is undertaken, the actions for an interested party are the same as those already explained in the Integrated Environmental Authorisation: the request for information about the Environmental Impact Study and starting project documentation, the application of the Urban Planning Report to the municipality, and the Statement of Community Interest, where appropriate.

The deadline for resolving and notifying the Environmental Permits shall be six months; after that time, with any express notification, the application will be understood as submitted, unless the license involves granting to the applicant or third parties rights related to public assets or public facilities, such as the use of public roads, in which case it shall be understood as rejected.

\subsection{Environmental liability statement and environmental communication}

Included in the system of Environmental Liability Statement are those activities that are not under Integrated Environmental Authorisations, nor in Environmental Permit regulations according to their minimal or nonexistent environmental impact, but that cannot be considered safe by not complying with any of the conditions of Annex III of the Law 6/2014, of 25 July (Table 2). 
46 Environmental and Economic Impact on Sustainable Development

Table 2: Activities included in Annex III of Law 16/2014 of environmental control of activities.

1. Noise and vibrations

1.1 To meet highest levels of airborne transmission or structure in law is sufficient as a unique measure correcting the mere absorption of walls and roof, by avoiding the maintenance of part of it as open areas.

1.2 Activities the average levels of sound pressure of which are standardised in the premise, weighted A, and should be lower than $70 \mathrm{dBA}$.

1.3. Those activities that have elements such as engines or motors whose power is equal to or less than $9 \mathrm{CV}$.

1.4. The activities with air conditioning equipment installed when:

- The compressor units are located within the premises, regardless of its power.

- When the installed power is less than nine horsepower (hp), regardless of its location.

2. Odours, smoke, and/or fumes

2.1 To avoid fumes and odours, it is sufficient to renew the air by blower machines.

2.2 No combustion or other physical or chemical processes that create gas fumes, vapours, and dust into the atmosphere are developed.

3. Air pollution

3.1. Those that are not included in the List of Atmospheric Potentially Polluting Activities contained in Annex IV of Law 34/2007, Air Quality and Protection of the Atmosphere, updated by Royal Decree 100/2011, of 28 January in either group a, B and $\mathrm{C}$, or law that substitutes or complements this.

4. Dumping of waste waters and/or wastes

4.1. - Do not require any prior purification of wastewater for discharge to public sewerage and/or the discharge consists only of sanitary waters.

4.2. - Do not produce waste or are equivalent to household waste.

5. Ionising radiation

5.1 Are not likely to issue any ionising radiation.

6. Fire

6.1 All those activities whose weighted thermal load is less than $100 \mathrm{Mcal} / \mathrm{m}^{2}$.

7. Handling of hazardous substances or hazardous waste generation.

7.1. Those activities that do not use, handle, or generate substances or waste deemed dangerous under the provisions of Annex III of the Law 22/2011, of July 28, about Waste and Contaminated Land or Annex I from the Regulation (EC) 1272/2008 of the European Parliament and of the Council of 16 December 2008 on classification, of labelling and packaging of substances and mixtures, for which is amended and revoked the directives 67/548/EEC and 1999/45/EC and Regulation (EC) 1907/2006 is modified.

8. Over pressure explosion and/or deflagration

9. Risk of Legionellosis (Legionnaire's disease)

9.1. Activities that do not have industrial facilities under maintenance programs included in Article 2 of RD 865/2003 of July 4, whereby health and hygiene criteria for the prevention and control of legionellosis (Legionnaire's disease)are regulated. 
The Liability Statement enables the initiation of performance of the activity without requiring any administrative authorisation by replacing prior control for any inspection after the start.

The term of validity covered for this activity is permanent; after completion of the Liability Statement, a subsequent opening license of the activity is not required, as is implied in the statement submitted to the city council when the facility is fully functioning.

The Liability Statement shall be accompanied by the technical report in which the installation and activity are described and a certification is signed by a competent engineer stating that the facility meets all technical and environmental conditions required to start the performance of the activity.

The effect of the statement is the initiation of the activity. Within a month after its submission, the City Council will verify the documentation and may visit, issuing the corresponding report. If the report is in compliance, the statement takes effect from that date; in contrast, if it is not in compliance, a period of rectification and a further inspection will be set, and after solving the disconformities, the activity will be started, or if not, it must be cancelled.

After the period of one month without inspection or no express decision of the city council, the activity can be initiated and an opening conformity certificate will be requested from the city council that is required to be issued in a month.

The exercise of other activities having no impact, considering such as those that meet all of the conditions referred to in Annex III shall require the submission to the city council of a Harmless Activity Communication prior to the start of the activity that is valid to perform the activity permanently.

The effect of communication is the opening and immediate start from submission, being in the hands of the city council the possibility of checking the truthfulness of the documentation provided and facility requirements at any time, in addition to pursuing environmental requirements by inspection resources and punishing those entitled by law.

\section{CONCLUSIONS}

A complete normative body guarantees the safety and the accomplishment of the general interest, but sometimes the difficult and extended administrative process created by it discourages enterprising activities by the private sector.

Concerning environmental control of planning and projects, several norms have been approved in the last 30 years; the massive regulation and the excessively protectionist interpretation by the administration have made the system complex and slow to pass by the applicant, who may refuse or assume the loss of business during this process.

Warned by the situation of dilatoriness in the resolution of environmental files, and even by the lack of investments, as it is been explained, the Valencian administration has started to increase efficiency in the procedures or has even attempted to avoid them in some particular situations.

However, there is still work to do in order to assemble the administrative control of environmental impact of projects, joining competences and fields of assessment.

\section{REFERENCES}

[1] Broseta Palanca, M.T., El control ambiental de actividades/The environmental control of activities,(Chapter 11). Legislación y gestión urbanística en la Comunidad Valenciana / Legislation and urban management in Valencian Community, ed. Tirant Lo Blanch: Valencia, pp. 197-212, 2015. 
48 Environmental and Economic Impact on Sustainable Development

[2] Almenar Muñoz, M., La tramitación de planes y programas. Especial referencia al procedimiento de evaluación ambiental / Plans and programmes processing. Special reference to environmental process (Chapter 1.VI), Nuevo Régimen Urbanístico de la Comunidad Valenciana. LOTUP / New Urban Legal System in Valencian Community. LOTUP, ed. Tirant Lo Blanch: Valencia, pp. 168-189, 2015.

[3] Broseta Palanca, M.T., La ordenación pormenorizada y el plan de ordenación pormenorizada. Los planes de desarrollo / The detailed planning and the plan for the detailed arrangement (Chapter 1.III), Nuevo Régimen Urbanístico de la Comunidad Valenciana. LOTUP / New Urban Legal System in Valencian Community. LOTUP, ed. Tirant Lo Blanch: Valencia, pp. 117-138, 2015.

[4] Casar Furió, M.E., Tratamiento del suelo no urbanizable en la LOTUP. Breve consideración del régimen de usos y edificación en el suelo urbanizable sin programación / The treatment of non-developable land in LOTUP (Chapter 4.I), Nuevo Régimen Urbanístico de la Comunidad Valenciana. LOTUP / New Urban Legal System in Valencian Community. LOTUP, ed. Tirant Lo Blanch: Valencia, pp. 824-873, 2015.

[5] Espinosa Baviera, J., Implantación de usos industriales y terciarios en suelo no urbanizable, en particular en la Comunidad Valenciana / Implementation of tertiary and industrial activities in non-developable land in Valencian Community, ed. Universidad Politécnica de Valencia, 2015.

[6] European Comission. Environment Policies Website, available at http://ec.europa.eu/ environment/index_en.htm

[7] Almenar Muñoz, M., La evaluación ambiental y estratégica del planeamiento territorial y urbanístico. Factores ambientales, riesgos y afecciones legales (en especial en la Comunidad Valenciana) / The strategic environmental assessment of territorial and urban planning. Environmental indicators, risks and legal impacts, Universidad Politécnica de Valencia: Valencia, 2015.

[8] Environmental Register of Installations, Consellería de Agricultura, Medio Ambiente, Cambio Climático y Desarrollo Rural / Consellería of Agriculture, Environmental, Climate Change and Rural Development website, Comunidad Valenciana, available at www.agricultura.gva.es/web/calidad-ambiental/registro-ambiental-de-instalaciones 